\title{
Donne's Holy Sonnets \\ and the Seven Penitential Psalms
}

ROMAN DUBINSKI

It has been customary since the seminal studies by Louis Martz and Helen Gardner to regard the "Holy Sonnets" as formal meditations inspired by continental treatises such as Ignatius Loyola's Spiritual Exercises. ${ }^{1}$ There can be little doubt that some of the sonnets are structured on the threefold method of meditation based on the faculties of memory, understanding, and will, while others seem to draw on the traditional meditation on the last things. But, in acknowledging the presence in the "Holy Sonnets" of meditative techniques, one is also aware of other formative influences that may be equal to if not more significant than the techniques of formal meditation. For instance, several critics connect the "Holy Sonnets" to the Psalms, especially the Seven Penitential Psalms. John Wall, Jr. suggests that the pattern of man's relationship to God found in the "Holy Sonnets" is similar to that in the Psalms, especially the group generally called laments. He cites Psalm 13 as an example and claims that Sonnet 10 ("Batter my heart, three person'd God") ${ }^{2}$ reveals the full pattern of the lament psalm. ${ }^{3}$ Rosemond Tuve, however, notes that "Batter my heart" is a variant of Psalm 102, one of the Penitential Psalms. ${ }^{4}$ More recently, Barbara Lewalski argues that, although Donne made no overt use of genretheory of the Psalms in his divine poems, he did make covert use. For instance, she points out that certain of the "Holy Sonnets," especially "Batter my heart," are imaginative re-revelations of the Penitential Psalms. The speaker of the "Holy Sonnets" seems to associate himself most closely with David in the Penitential Psalms and with Paul in the Epistles. And finally, Lewalski notes in passing several echoes from the Penititential Psalms in the "Holy Sonnets."s

Though not dealing specifically with English poetry, Terence Cave's important study of devotional poetry in late sixteenth- and early seventeenthcentury France offers relevant contexts for a study of Donne's "Holy Sonnets." Cave examines the extent to which verse paraphrases of the Penitential Psalms inspired both psalm-like lyrics and sonnets on penitential themes. These paraphrases, along with other penitential material from 


\section{2 / Renaissance and Reformation}

the Old Testament, provided poets with a particular pattern of themes, a certain cast of language, and a roomy and flexible form that could cope with all the modulations of penitential devotion-lament, self-deprecation, and prayer. Cave further observes that because of the popularity of the sonnet form, it was virtually inevitable that poets would seek to transform the equivalent of a Penitential Psalm into a sonnet. And, in a remark that is suggestive for Donne's "Holy Sonnets," Cave explains that in some cases the sequence replaced the form of the individual sonnet so that the sonnet became a paragraph in a more extended meditation. ${ }^{6}$ Cave's work on penitential poetry in France offers some important leads, not only for an examination of the "Holy Sonnets," but also for a broader study of English poetry on penitential themes. ${ }^{7}$ The penitential nature of the "Holy Sonnets" has in fact been discussed by D.L. Peterson, though he makes no specific reference to the Penitential Psalms. Peterson argues that the controlling principle of the "Holy Sonnets" is the Anglican doctrine of contrition. The poems represent a series of efforts to experience those states of feeling that either precede or are concomitant with contrition. He adds that the four sonnets added in the 1635 edition are explicitly penitential. ${ }^{8}$

This brief survey shows that several critics have established connections between the "Holy Sonnets" and the Seven Penitential Psalms, though for the most part their comments have been allusive and peripheral. Their comments, however, provide warrant for a more extensive study of the formative influence of these Psalms on the "Holy Sunniets." The specific place of the Penitential Psalms in Christian devotion and the Donne's interpretation of them will serve as a preface to this study.

As a group particularly apt for the devotional needs of penitent sinners, the Seven Penitential Psalms $(6,32,38,51,102,130,143$ in the Authorized Version) have a long history in the church, dating back to at least the sixth century when they were isolated and named by Cassiodorus. ${ }^{9}$ They had regular uses in the Divine Office, ${ }^{10}$ and in the medieval church were appointed to persons who were reunited to the church after satisfying open, canonical penance. ${ }^{11}$ Commentators have described these psalms as a ladder of repentance, each psalm representing one step. ${ }^{12}$ Their number, seven, was seen as particularly appropriate, for they were designated as seven weapons with which to oppose the seven deadly sins, seven prayers inspired by the sevenfold spirit to the repenting sinner, seven guardians for the seven days of the week, and seven companions for the seven canonical hours of the day. ${ }^{13}$ The Penitential Psalms continued to enjoy favour among Protestants of the Reformation era. For instance, they attracted commentary as a group by Luther ${ }^{14}$ and served as a focus for meditation by Theodore Beza. ${ }^{15}$ They were also frequently paraphrased by poets, both in England and on the continent. ${ }^{16}$ Their status as a popular devotion for the layman, however, is most likely attributable to their presence as one of the 
standard offices in both pre-Reformation and post-Reformation Primers. ${ }^{17}$

That the Psalms as a whole, and the Penitential Psalms in particular, attracted Donne's special interest is made plain by his own testimony in the sermons. In one of his earlier sermons, Donne isolates the Psalms as his favourite Old Testament scripture:

I acknowledge, that my spirituall appetite carries me still, upon the Psalms of David, for a first course, for the Scriptures of the Old Testament, and upon the Epistles of Saint Paul, for a second course, for the New: and my meditations even for these publike exercises to Gods Church, returne oftnest to these two. ${ }^{18}$

He is drawn to the Psalms not only because Church Fathers such as St. Augustine loved them, but for a personal reason:

I may have another more particular reason, because they are Scriptures, written in such forms, as I have been most accustomed to; Saint Pauls being Letters, and Davids being Poems. ${ }^{19}$

Donne's own practice as a poet gives particular force to his description of the poetic quality of the Psalms:

he [God] gives us our instruction in cheerfull forms, ... in Psalms, which is also a limited, and a restrained form; Not in an Oration, not in Prose, but in Psalms; which is such a form as is both curious, and requires diligence in the making, and then when it is made, can have nothing, no syllable taken from it, nor added to it :... God speaks to us in oratione stricta, in a limited, in a diligent form; Let us [not] speak to him in oratione soluta; not pray, not preach, not hear, slackly, suddenly, unadvisedly, extemporally, occasionally, indiligently; but let all our speech to him, be weighed, and measured in the weights of the Sanctuary....20

Donne clearly believes that God's way of speaking to man in the Psalms should serve as a model for man when he speaks to God in prayer. His preference for set forms of prayer and his opposition to prayers that are slack, sudden, unadvised, extemporal are also evident. The views expressed here are not novel, for they represent Donne's characteristic attitude to prayer. ${ }^{21}$ And when Donne chose poetry as his medium of prayer, all of his poems seem to represent "such a form as is both curious, and requires diligence in the making, and then when it is made, can have nothing, no syllable taken from it, nor added to it." This remark applies forcefully not only to poems of intricate workmanship like "La Corona," but also to the "Holy Sonnets."

Donne's affection for the Psalms and his preference for them as a model for prayer also comes out strongly in his poem "Upon the translation of the Psalmes by Sir Philip Sydney, and the Countesse of Pembroke his Sister." Donne first praises God for bestowing his Spirit upon David, the author of the Psalms, so that "he sung / The highest matter in the noblest forme." 
Now, God's Spirit has once again descended, this time upon the Sidneys, brother and sister, who sing the Psalms anew:

\author{
The songs are these, which heavens high holy Muse \\ Whisper'd to David, David to the Jewes: \\ And David's Successors, in holy zeale, \\ In formes of joy and art doe re-reveale \\ To us so sweetly and sincerely too.
}

The Sidneian psalm paraphrases are, then, a re-creation or re-revelation of the original inspiration, and it is as much their artistry, their "noblest forme," as their "highest matter" that encourages Donne to hope that versions like the Sidneys' may become the Church's songs of praise instead of the artistically inferior Sternhold-Hopkins Old Version used in the English service:

\footnotetext{
When I behold that these Psalmes are become

So well attyr'd abroad, so ill at home,

So well in Chambers, in thy Church so ill,

As I can scarce call that reform'd untill

This be reform'd.
}

Donne's remarks, both in the sermons and in his poem on the Sidneian Psalms, emphatically confirm that he regarded the Psalms as a most apt model for prayer. Prayer in verse could take the form of either paraphrases of the Psalms in the vernacular or original poems recreating their style and substance. Barbara Lewalski has demonstrated in detail how the Psalms spawned an enormous number of paraphrases and provided important models for poets composing original devotional poems. She has also argued that Donne's commentary in the sermons provides the most coherent "literary" view of the basic kinds of lyric in the Psalms. ${ }^{22}$ His sensitivity to their sophisticated poetic forms and to their character as an anatomy of the soul in prayer make it seem natural that, when he came to sing his own "prayers and praises," he would find rich inspiration in the Psalms. And in composing the "Holy Sonnets" Donne turned in particular to the Seven Penitential Psalms.

The central situation of the first sixteen of the "Holy Sonnets" (those composed in 1609-10) of a sinner becoming aware of his alienation from God, recognizing his impotence and his absolute dependence upon God's initiative, crying in anguish to God to come to his rescue before sickness and death overcome him, and periodically rejoicing in the remembrance that Christ through his Passion has already redeemed him from sin reproduces quite closely the situation of the psalmist in the Penitential Psalms. Like those Psalms, the group of sixteen "Holy Sonnets" is not a sequence with a precise beginning, middle and end tracing a pattern from lament and 
despair to a resolution in renewed faith and hope. Rather, as John Wall, Jr. argues, the "Holy Sonnets" show dramatic movement, but no progress. The poems are marked by the rapid alternation of emotions, the poet now lapsing and now aspiring, but never resting long in any one stance. Ultimately, concludes Wall, the poet's movement is circular, not spiral; his goal is not resolution, but acceptance of the paradoxes of Christian life on earth. ${ }^{23}$

Barbara Lewalski agrees with Wall about the lack of sequence in the "Holy Sonnets." After reviewing the textual evidence, she claims that it is well-nigh impossible to argue conclusively any question of sequence. As a result, she accepts the 1635 ordering made conventional by Grierson over the 1633 ordering accepted by Helen Gardner. Donne, she suggests, may not have intended the sonnets as a sequence, but as various discrete moments in the speaker's spiritual drama. Indeed, from the Protestant perspective, the question of sequence is irrelevant, for the various spiritual states subsumed under the paradigm of salvation are not so much sequential as concomitant. They may and should be newly experienced and relived at any time. ${ }^{24}$

Though she notes that the "Holy Sonnets" are permeated with echoes of the Psalms (including the Penitential Psalms), Lewalski is mainly concerned to elucidate the way they are suffused with the Pauline language and theological concepts making up what she has called the Protestant paradigm of salvation - election, calling, justification, adoption, sanctification, glorification. ${ }^{25}$ The reasons for Donne's use of this language in poems based on the Penitential Psalms are made clear when one examines the characteristic way in which he interprets these Psalms in his sermons.

It is significant that of the 160 extant sermons, 34 are on the Psalms, with 21 devoted to texts from the Penitential Psalms. Of equal importance is Donne's explanation of the way he reads and interprets those Psalms. When he describes the Penitential Psalms as "the Churches Topicks for mortification and humiliation," ${ }^{26}$ Donne implies that they can be used now by the Church as part of its work to bring sinners to repentance. What this means is that Donne reads the Psalms typologically. In several of his sermons on the Penitential Psalms, Donne makes explicit his typological reading:

these Psalmes were made, not onely to vent Davids present holy passion, but to serve the Church of God, to the worlds end. ${ }^{27}$

for this Psalm [38], some of our Expositors take to be a historicall, and personall Psalm, determin'd in David; some, a Catholique, and universall Psalm, extended to the whole condition of man; and some a Propheticall, and Evangelicall Psalm, directed upon Christ. None of them inconveniently; for we receive help and health, from every one of these acceptations. ${ }^{28}$ 
First then, all these things [Ps. 38:4] are literally spoken of David; By application, of us; and by figure, of Christ. Historically, David; morally, we; Typically, Christ is the subject of this text. ${ }^{29}$

Specific examples of Donne's typological readings will demonstrate how he interprets the Old Testament experience of David the penitent sinner as a prefiguration or type of the experience of all sinners and as a prophecy of Christ, who took upon himself all sin. In a sermon on Ps. 38:4 Donne not only recounts the multiplicity and heinousness of David's sins, but claims that "David speaks prophetically, as well as personally, and to us, ... That which David relates to have been his own case, he foresees will be ours too, in a higher degree." ${ }^{30}$ We need, declares Donne in a sermon on Ps. 51:7, "no other Example to discover to us the slippery wayes into sin, or the penitentiall wayes out of sin, then ... David." 31 David's lamentations over the misery induced by sins and his cries for mercy look forward to the figure of Christ, the man of sorrows, who in his Passion took upon himself all the pain and torment of sin, who experienced intensely the anguish of David and all other sinners, and who in his suffering called out to God for mercy. As Donne explains in a sermon on Ps. 38:3:

surely he [Christ] hath borne our griefes, and carried our sorrows, he was wounded for our transgressions, and bruised for our iniquities. ${ }^{32}$

In his application of David's condition to Christ and to all sinners it would be natural for Donne to translate the language of the psalmist's prayer into the language and theological concepts of the Pauline Epistles. When he explicates the typological significance of David's petition to be purged with hyssop (Ps. 51:7), Donne comments:

That hee might have the blood of Christ Jesus applied and sprinkled upon him; David thought of no election, hee looked for no sanctification, but in the blood of Christ Jesus. And then he desired this blood to be applied to him, by that Hyssope, by that Blood-sprinkler, which was ordained by God, for the use of the Church. ${ }^{33}$

And in explaining the second half of David's petition "Wash me, and I shall be whiter then snow" (Ps. 51:7), Donne reads it as David's request for the "gift of sanctification, and perseverance," for the granting of "A continuall succession of Grace, working effectually to present Habits of religious acts, and constituting a holy purpose of persevering in them."34

The language Donne uses in reading the Penitential Psalms typologically - election, sanctification, perseverance - is the language of the Protestant paradigm of salvation. In a sense, Donne has poured new wine into old bottles. The Psalms speak to man's spiritual condition in the language of the 
Old Testament. Donne transforms this language to talk about the same condition in the language of the New Testament. J.C. Rathmell remarks that one of the significant features of the Sidney paraphrases of the Psalms is the way they "constantly bring out and point the underlying 'allegoricall sense.' Sidney and the Countess of Pembroke have clearly made intelligent use of a wealth of scholarly commentary that was not so readily accessible to the earlier psalmodists." ${ }^{35}$ By the "allegoricall sense" Rathmell clearly means the typological sense. His comment is important here because it indicates that paraphrases of the Psalms either implicitly or explicitly translated the Psalms into the language of the New Testament. As Marshall and Todd explain, the Christian element was present in the paraphrases of the Psalms both by virtue of adaptation and by virtue of the traditional typological interpretation in both sermon and commentary. ${ }^{36}$ Though readers of the Psalms would be familiar with the typological meanings, nevertheless, as Louis Benson claims, there was a growing effort all through the seventeenth century to accommodate the psalm texts to the circumstances of present day worshippers. The first step in this process was to introduce the familiar interpretations into the actual texts of the Psalms. Its culmination is represented by Isaac Watts's The Psalms of David, Imitated in the Language of the New Testament, and Applied to the Christian State and Worship (1719). ${ }^{37}$ An example of how Watts "translates" passages from one of the Penitential Psalms will demonstrate the process. Watts entitles Psalm 32 "Repentance and free Pardon; or, Justification and Sanctification." The first two verses of Psalm 32 in the Authorized Version are as follows:

Blessed is he whose transgression is forgiven, whose sin is covered. Blessed is the man unto whom the Lord imputeth not iniquity, and in whose spirit there is no guile.

Here is one of Watts's "translations" of these verses:

Blest is the man, for ever blest,

Whose guilt is pardon'd by his God, Whose sins with sorrow are confess'd, And cover'd with his Saviour's blood.

Blest is the man to whom the Lord Imputes not his iniquities, He pleads no merit or reward, And not on works, but grace relies. ${ }^{38}$

The explicit references to Christ's saving blood and to the doctrine of justification by faith alone show how Watts accommodated the Psalms to the language and theology suitable for a contemporary Protestant. The gloss in 
the Geneva Bible, for instance, interprets these verses in the standard Protestant way: "To be iustified by faith, is to have our sinnes frely remitted, and to be reputed iust, Rom. 4,6."

Since Donne and his contemporaries routinely read the Penitential Psalms typologically, it should not be surprising that in composing poems inspired by these Psalms, Donne too, like Watts later, would transform analysis of the psalmist's spiritual state into the language of the new dispensation more applicable to a seventeenth-century Protestant. So when the speaker in Sonnet 1 cries "Oh I shall soone despaire, when I doe see / That thou lov'st mankind well, yet wilt' not chuse me," it is clear that he is worried about his election. His petition to God in Sonnet 3, "Impute me righteous," refers specifically to justification, the effect of the imputation of Christ's righteousness. And when the speaker in 10 pleads with God,

Batter my heart, three person'd God; for, you

As yet but knocke, breathe, shine, and seeke to mend;

That I may rise, and stand, o'erthrow mee,' and bend

Your force, to breake, blowe, burn and make me new,

he is referring explicitly to regeneration and sanctification.

In composing original poems based on the Penitential Psalms, it would be quite natural, then, for Donne to "re-reveale" David's prayers in the language of the Pauline paradigm of salvation. What Cave says about the penitential lyric in France can be applied to the "Holy Sonnets." Like the penitential lyrics, Donne's sonnets recreate and develop all the modulations of lament, self-deprecation and prayer in a way that gives the impression of controlled improvisation on an established theme. ${ }^{39}$ The spiritual situation of the Penitential Psalms forms the basis for Donne's improvisations in the "Holy Sonnets," but the improvisations are in a new key affected by the typological transference of the psalmist's situation to that of an early seventeenth-century Protestant.

The typological perspective is important for understanding the language and theology of the "Holy Sonnets," but it is in their nature as prayers that they most resemble the Penitential Psalms. Though he recognizes that the Psalms comprise various categories, Donne finds that most fundamentally they are prayers and praises. The whole Book of Psalms is a Book of Praise, but the parts are prayers: "The name changes not the nature; Prayer and Praise is the same thing: ... these two parts of our devotion, Prayer and Praise ... accompany one another ... they meet like two waters, and make the streame of devotion the fuller." 40 The specific elements of prayer are given more extended treatment in Donne's explication of Paul's exhortation in 1 Tim. 2:1: 
I exhort therefore, that, first of all, supplications, prayers, intercessions, and giving of thanks, be made for all men.

This text, claims Donne, shows how the various kinds of prayer imply "certaine gradations, and steps, and ascensions of the soul in prayer."41 The Penitential Psalms in particular, declares Donne, are primarily supplications and prayers, which comprise two parts - deprecatory or postulatory, "something David would have forborne, and something done."42 Drawing on the same text from 1 Timothy 2, Lancelot Andrewes describes a scheme of prayer that is similar to Donne's, though more comprehensive. Prayer may include either petition or thanksgiving. Petitions may be for ourselves in the form of deprecations and precations (i.e. expostulations), or they may be for others (intercessions). Prayer also involves confession of sins to God with supplication for pardon, as well as praise to God for pardoning our sins and for bestowing benefits. ${ }^{43}$

As prayers, both the Penitential Psalms and the "Holy Sonnets" primarily adopt the dramatic pose of the sinner addressing God directly. All the Psalms and nine of the sixteen "Holy Sonnets" are structured as dramatic monologues. In three of the Psalms, the dramatic colloquy with God gives way in part either to God's direct instruction of the psalmist $(32: 8,9)$ or to the psalmist delivering instructions to the congregation $(102: 16-23 ; 130: 7-8)$. Parallels for these instructional elements can be found in four of the "Holy Sonnets" $(2,9,11,16)$ where the speaker functions as a preacher or instructor for his own soul.

Within this dramatic context, both Penitential Psalms and "Holy Sonnets" exploit nearly all the varieties of prayer outlined by Donne and Andrewes. Donne appropriates and recreates the characteristic mix of prayers found in the Penitential Psalms - lamentations, deprecations and postulations, confessions, and thanksgivings and praises. Though one can recognize some direct verbal borrowings, for the most part Donne reworks the substance of the Psalm prayers in a new key and in his own stylistic timbre.

Illustration of the specific tonal quality of the different elements of prayer in the Penitential Psalms will facilitate a more acute appreciation of the way Donne has appropriated this material into the "Holy Sonnets."44 The Penitential Psalms, which grow out of the psalmist's precarious physical and spiritual condition, lead to the frequent and recurrent note of lamentation. "I am weak" ( $6: 2)$, cries the psalmist, "my bones are vexed" (6:2); "My soul is also sore vexed" (6:3); "day and night thy hand was heavy upon me" (32:4); "thine arrows stick fast in me, and thy hand presseth me sore" (38:2); "there is no soundness in my flesh because of thine anger; neither is there any rest in my bones because of my sin" (38:3); "I am feeble and sore broken" (38:8); "my days are consumed like smoke, and my 
bones are burned as an hearth" (102:3). These recurring cries of heartfelt pain establish the poet's need for help, which appears in his postulations and deprecations, and which create much of the dramatic urgency of these Psalms. The deprecations call on God to desist and relent in his anger and in his alienation from the psalmist: "rebuke me not in thine anger, neither chasten me in thy hot displeasure" (6:1); "Forsake me not, O Lord: O my God, be not far from me" (38:21); "Cast me not away from thy presence; and take not thy holy spirit from me" (51:11); "hide not thy face from me", (143:7). The postulations or petitions, on the other hand, implore God not only to hear the psalmist's impassioned prayers, but also to forgive his sins, cleanse him, and restore him to favour. "Have mercy upon me ... heal me" (6:2); "save me for thy mercies' sake" (6:4); "Make haste to help me" (38:22); "Wash me thoroughly from mine iniquity, and cleanse me from my sin" (51:2); "Purge me with hyssop, and I shall be clean: wash me, and I shall be whiter than snow" (51:7); "Create in me a clean heart, O God; and renew a right spirit within me" (51:10); "Restore unto me the joy of thy salvation; and uphold me with thy free spirit" (51:12); "Hear my prayer, O Lord, give ear to my supplications: in thy faithfulness answer me, and in thy righteousness" (143:1). The psalmist realizes that before God will hear him and answer his prayers, he has to acknowledge his sinfulness and show proper contrition. "I acknowledged my sin unto thee, and mine iniquity have I not hid: . . . I will confess my transgressions unto the Lord" (32:5); "For I will declare mine iniquity; I will be sorry for my sin" (38:18); "Against thee, thee only, have I sinned, and done this evil in thy sight" (51:4). From time to time, the psalmist with renewed faith and hope gives thanks that his prayers have been answered and that God has not abandoned him. "The Lord hath heard the voice of my weeping. The Lord hath heard my supplication; the Lord will receive my prayer" (6:8-9); "thou forgavest the iniquity of my $\sin ^{\prime \prime}(32: 5)$; "Be glad in the Lord, and rejoice, ye righteous: and shout for joy, all ye that are upright in heart" (32:11); "Let Israel hope in the Lord: for with the Lord there is mercy, and with him is plenteous redemption. And he shall redeem Israel from all his iniquities" (130:7-8).

Close examination of the "Holy Sonnets" reveals precisely the same elements of prayer. Lamentation inspired by consciousness of sin is intensified by the speaker's sickness and by his fear of impending death. In Sonnet 2 , the speaker, summoned by sickness, "deaths herald, and champion," imagines himself as a thief who has heard "deathes doom" and now trembles in fear of being "hal'd to execution." The speaker in Sonnet 3, faced with the imminence of "gluttonous death" that "will instantly unjoynt" "body, and soule" shakes with fear at the thought of facing his Creator at the Last Judgment. Divine Meditations 1, however, echoes the laments in the Penitential Psalms most closely: 
Thou hast made me, And shall thy worke decay?

Repaire me now, for now mine end doth haste,

I runne to death, and death meets me as fast,

And all my pleasures are like yesterday,

I dare not move my dimme eyes any way,

Despaire behind, and death before doth cast

Such terrour, and my feebled flesh doth waste

By sinne in it, which it t'wards hell doth weigh.

These anguished laments reproduce the substance and tone of similar laments in Psalms 38 and 102:

My wounds stink and are corrupt because of my foolishness. I am troubled; I am bowed down greatly; I go mourning all the day long. For my loins are filled with a loathsome disease: and there is no soundness in my flesh. I am feeble and sore broken: I have roared by reason of the disquietness of my heart.... My heart panteth, my strength faileth me: as for the light of mine eyes, it also is gone from me. (38:5-10)

Hide not thy face from me in the day when I am in trouble; incline thine ear unto me: in the day when I call answer me speedily. For my days are consumed like smoke, and my bones are burned as an hearth. My heart is smitten, and withered like grass; so that I forget to eat my bread. (102:2-4)

The laments in the "Holy Sonnets" regularly provoke petitions from the speaker calling on God to help him in his distress. Specifically, the poet knows that he needs to repent for his sins, but also acknowledges that he needs God's grace to begin the process of repentance. In these postulations for God's initiative, Donne has transformed the psalmist's supplications for God to hear him and to save him into the language of the new dispensation.

After rehearsing God's many mercies to man, from creation to redemption, the speaker in Sonnet 1 realizes that when he betrayed himself through sin, he became alienated from God and passed under the domain of the devil. Now, helpless and impotent, he calls desperately on God to rise and fight for him. In Divine Meditations 1, the speaker, sensing that he is sinking to hell beneath the burden of his sins, experiences total helplessness in the face of the devil's temptations. Only God's grace can save him:

Thy Grace may wing me to prevent his art

And thou like Adamant draw mine iron heart.

The frequent pleas for cleansing and purification that appear in the Penitential Psalms also find a prominent place in the "Holy Sonnets." The speaker in Sonnet 2 becomes aware of the first stirrings of God's grace 
working in his heart when he realizes that sorrow for one's sins and contrition are the first steps on the way back to God:

O make thy selfe with holy mourning blacke,

And red with blushing, as thou art with sinne;

Or wash thee in Christs blood, which hath this might

That being red, it dyes red soules to white.

The reference to Christ's blood is a clear sign that one of the effects of God's grace, saving faith, has become discernible in the speaker. This same saving faith appears at the end of Sonnet 4:

Teach mee how to repent; for that's as good

As if thou 'hadst seal'd my pardon, with thy blood.

In accents closer to the Penitential Psalms, the speaker in Divine Meditations 2 calls for a purifying cleansing, either by water or by fire:

Powre new seas in mine eyes, that so I might
Drowne my world with my weeping earnestly,
Or wash it, if it must be drown'd no more:
But oh it must be burnt; alas the fire
Of lust and envie have burnt it heretofore,
And made it fouler; Let their flames retire,
And burne me o Lord, with a fiery zeale
Of thee and thy house, which doth in eating heale.

One can hear echoes of Psalm 51 in these pleas for purification:

Wash me thoroughly from mine iniquity, and cleanse me from my sin.... Purge me with hyssop and I shall be clean: wash me, and I shall be whiter than snow. $(51: 2,7)$

The psalmist's petition in 51:10 that God remake him ("Create in me a clean heart, $\mathrm{O}$ God; and renew a right spirit within me") is given most forceful and dramatic expression in Sonnet 10:

\footnotetext{
Batter my heart, three person'd God; for you

As yet but knocke, breathe, shine, and seeke to mend;

That I may rise, and stand, o'erthrow mee,' and bend

Your force, to breake, blowe, burn and make me new.
}

The note of confession and contrition permeates both the Penitential Psalms and the "Holy Sonnets." It appears explicitly in Sonnet 5. In the octave the speaker seeking to excuse himself from responsibility for sin, chafes at and resents God for damning man in his stern wrath. But in the sestet he draws back in horror at his pride and presumption and humbly begs God to accept his tears of contrition: 
But who am I, that dare dispute with thee?

O God, Oh! of thine onely worthy blood,

And my teares, make a heavenly Lethean flood,

And drown in it my sinnes black memorie.

That thou remember them, some claime as debt,

I think it mercy, if thou wilt forget.

In Divine Meditations 3, the poet regrets how in his sinful past he wasted his tears in his idolatrous love affairs. Now he asks that those sighs and tears return so

That I might in this holy discontent

Mourne with some fruit, as I have mourn'd in vaine.

The element of thanksgiving in the Penitential Psalms finds a prominent place in the "Holy Sonnets," but in a form that is appropriate to the typological perspective of a Christian living under the new dispensation. The psalmist's beatitude in Ps. 32:1-2, "Blessed is he whose transgression is forgiven, whose sin is covered. Blessed is the man unto whom the Lord imputeth not iniquity," takes on particular resonance in the context of man's redemption through the shedding of Christ's blood on the cross. By taking upon himself all sin and all punishment for sin, Christ has once and for all removed the burden of sin from all men. What is left for man under the new law is to offer thanksgiving to his saviour for the gift of redemption. This thanksgiving becomes the focus of a group of "Holy Sonnets" that records the speaker's gratitude for Christ's act of saving love $(7,8,9,11$, 12). The poet's impulse in Sonnet 7 to offer himself to bear the brunt of the "Jewes impiety" in place of Jesus seems just and noble, but in fact betrays his lack of understanding of the need for a pure and innocent sacrifice to pay the necessary price for man's default. The poet admits that even though he has been glorified by Christ, his sins continue to crucify his redeemer. This insight prompts his remembrance that all that is left to him now is a grateful heart:

Oh let mee then, his strange love still admire:

King's pardon, but he bore our punishment.

The poet's wonder in Sonnet 8 that all creation has been subdued to serve unworthy man's needs is exceeded by his gratitude for a greater wonder:

But wonder at a greater wonder, for to us

Created nature doth these things subdue,

But their Creator, whom sin, nor nature tyed,

For us, his Creatures, and his foes, hath dyed. 
The thoughts of death and fear of judgment are mitigated in Sonnet 9 by the poet's assurance that the beautiful picture of Christ crucified that resides in his heart guarantees mercy and forgiveness:

To wicked spirits are horrid shapes assign'd,

This beauteous forme assures a pitious minde.

In Sonnet 11, the speaker instructs his soul in God's love as revealed in the operation of the Holy Trinity. God the Spirit has made his temple in his breast, God the Father has chosen him to be his son by adoption, and God the Son "came downe, and was slaine, / Us whom he'had made, and Satan stolne, to unbinde." By meditating on God's many acts of love, the soul learns about love and returns it in gratitude to its source. Finally, Sonnet 12 ends with the speaker's understanding of the epitome of God's law:

Thy lawes abridgement, and thy last command

Is all but love; Oh let that last Will stand!

The similarity in dramatic situation, in tone, and in a combination of parallel elements of prayer make it highly likely that the Penitential Psalms were a crucial formative influence on the "Holy Sonnets." It has been customary to describe the "Holy Sonnets" as meditations inspired by continental treatises such as Loyola's Spiritual Exercises. It seems even more likely that Donne found his inspiration in works that he admired as poems and that provided a precedent for the impassioned penitential prayer that characterizes the "Holy Sonnets." Biographically-oriented critics like to read the "Holy Sonnets" and the other divine poems written between 1608 . and 1610 as reflections of a spiritual crisis Donne was experiencing. That may be so, but there is also evidence that Donne intended the poems of these years to be used in the private devotions of his friends. He sent " $\mathrm{La}$ Corona" along with a letter and prefatory sonnet to Mrs. Magdalen Herbert. "A Litanie" was intended for service in "lesser Chappels, which are my friends." And at least the first six of the "Holy Sonnets" were sent to the Earl of Dorset along with a dedicatory sonnet. ${ }^{45}$ Although it lies beyond the scope of this essay, it would be worth studying the relationship between these three poems and some of the standard devotions found in the layman's prayer book, the Primer. As a devotion based on Christ's life, "La Corona" has clear connections with the offices of the Blessed Virgin and the Holy Cross, which focus on the beginning and end of Christ's life. In the Primers, the Seven Penitential Psalms and the Litany are usually placed together and serve as a penitential devotion, generally recommended for the evenings. Donne's "Holy Sonnets" and "A Litanie" clearly parallel these Primer devotions. The Penitential Psalms in the Primer are usually accompanied by woodcuts showing either David the sinner gazing 
in lust on the naked Bathsheba or the repentant David praying on his knees, ${ }^{46}$ the precise aspects Donne gives prominence to in his sermons on the Penitential Psalms. It seems quite plausible, then, that in sending his "Holy Sonnets" to his friends, Donne would expect them to complement the Penitential Psalms as part of their evening penitential devotions.

\section{University of Waterloo}

\section{Notes}

1 Louis Martz, The Poetry of Meditation (New Haven: Yale University Press, 1965), pp. 43-56; Helen Gardner, ed., John Donne: The Divine Poems (Oxford at the Clarendon Press, 1966), pp. xlix-lv.

2 All citations from the divine poems will be from Gardner's edition.

3 John Wall, Jr., “Donne's Wit of Redemption: The Drama of Prayer in the Holy Sonnets," SP, 73 (1976), 198-99.

4 Rosemond Tuve, A Reading of George Herbert (Chicago: The University of Chicago Press, 1969), p. 178.

5 Barbara Lewalski, Protestant Poetics and the Seventeenth-Century Religious Lyric (Princeton: Princeton University Press, 1979), pp. 52, 245, 266, 268.

6 Terence Cave. Devotional Poetry in France c. 1570-1613 (Cambridge: Cambridge University Press, 1969), pp. 95-103, 135-36.

7 For instance, William Alabaster composed a group of eight "Penitential Sonnets" around 1597 or 1598. See The Sonnets of William Alabaster, ed. G.M. Story and Helen Gardner (Oxford: Oxford University Press, 1959), pp. 7-10. It is possible that Donne knew Alabaster's poetry, even though it remained in manuscript until the twentieth century. In a letter to Sir Henry Goodyer dated 14 March 1614, Donne reports that "Mr Alabaster hath got of the King the Deans best Living worth above 300 l." (Letters to Severall Persons of Honour [1651]. A Facsimile Reproduction, with an Introduction by M. Thomas Hester [Delmar, N.Y.: Scholars' Facsimiles and Reprints, 1977], p. 168.) R.C. Bald suggests that Donne may have known Alabaster ever since 1596, when he had been Essex's chaplain on the Cadiz expedition (John Donne: A Life [Oxford at the Clarendon Press, 1970], p. 282).

8 D.L. Peterson, "John Donne's Holy Sonnets and the Anglican Doctrine of Contrition," SP, 56 (1959), 506-08, 513-14. Patrick Grant agrees with Peterson that contrition is at the center of the "Holy Sonnets." See The Transformation of Sin (Montreal: McGill-Queen's University Press, 1974), p. 60.

9 John Harthan, The Book of Hours, with a Historical Survey and Commentary (New York, 1977), p. 17.

10 For the place of the Penitential Psalms in the various uses of the liturgy, see J.M. Neale and R.F. Littledale, A Commentary on the Psalms (New York: AMS Press, 1976), 4 vols.

11 Lewalski, Protestant Poetics, p. 46.

12 Neale and Littledale, I, 126.

13 Neale and Littledale, I, 125. In the Sarum Breviary the Penitential Psalms are identified with the seven deadly sins as follows: 6 (Anger), 32 (Pride), 38 (Gluttony), 51 (Lechery), 102 (Avarice), 130 (Envy), 143 (Sloth). See Brevarium ad Usum Insignis Ecclesiae Sarum, ed. Francis Procter and Christopher Wordsworth (Cambridge: Cambridge University Press, 1882), II, 241-49.

14 Luther's Works, ed. Jaroslav Pelikan and Daniel Poellot(St. Louis: Concordia Publishing House, 1958), Vol. 14.

15 Theodore Beza, Christian Meditations upon eight Psalmes of the Prophet David, trans. I.S. [John Stubs] (London, 1582). 


\section{6 / Renaissance and Reformation}

16 For paraphrases in France, see Cave, p. 97. Among the earliest paraphrases in England are those by Wyatt. See Collected Poems of Sir Thomas Wyatt, ed. Kenneth Muir and Patricia Thomson (Liverpool: Liverpool University Press, 1969), pp. 98-125.

17 For a study of the popularity of the Primer in the sixteenth century, see Helen C. White, The Tudor Books of Private Devotion (The University of Wisconsin Press, 1951), pp. 53-133.

18 The Sermons of John Donne, ed. Evelyn M. Simpson and George R. Potter, 10 vols. (Berkeley: University of California Press, 1953-62), II, 49.

19 Sermons, II, 49.

20 Sermons, II, 49-50.

21 See Donne's preference for set prayers in Sermons, IV, 311 where he advises "mustering up those words, which the Church hath levied for that service, in the Confessions, and Absolutions, and Collects, and Litanies of the Church."

22 Lewalski, Protestant Poetics, pp. 39-53.

23 Wall, pp. 190-91, 203.

24 Lewalski, Protestant Poetics, p. 265.

25 Lewalski, Protestant Poetics, p. 265. For her analysis of the paradigm of salvation, see pp. 13-27.

26 Sermons, VIII, 193.

27 Sermons, II, 55.

28 Sermons, II, 75.

29 Sermons, II, 97.

30 Sermons, II, 99.

31 Sermons, V, 299.

32 Sermons, II, 92.

33 Sermons, V, 310.

34 Sermons, V, 312-13.

35 The Psalms of Sir Philip Sidney and the Countess of Pembroke (New York: New York University Press, 1963), p. xiv. For a general study of the prevalence of typology in religious poetry, see Lewalski, Protestant Poetics, pp. 111-44.

36 Madeleine Marshall and Janet Todd, English Congregational Hymns in the Eighteenth Century (University of Kentucky Press, 1982), p. 14.

37 Louis Benson, The English Hymn: Its Development and Use in Worship (Richmond, Va.: John Knox Press, 1962), pp. 51-53.

38 The Works of the Reverend and Learned Isaac Watts, compiled by the Rev. George Burder(London, 1810), IV, 148.

39 Cave, pp. 103-05.

40 Sermons, V, 270.

41 Sermons, V, 341.

42 Sermons, V, 338.

43 The Private Devotions of Lancelot Andrewes, trans. with an introduction and notes by F.E. Brightman (New York: Meridian Books, 1961), p. 11.

44 Quotations from the Psalms will be from the Authorized Version which Donne used in his sermons on the Psalms.

45 See Gardner, pp. 55-56, 64, 81.

46 For the former woodcut see Thys prymer in Englyshe and in Laten is newly translatyd after the Laten texte (Rouen, 1536); for the latter see The Primer, or Office of the Blessed Virgin Marie, in Latin and English 1599 (The Scolar Press, 1975). 